\title{
COOPERATION AND THE RELATIONSHIP BETWEEN EDUCATION AND HEALTHCARE INSTITUTIONS: THE NURSING PRÓ-SAÚDE PROJECT
}

\author{
Selma Regina de Andrade ${ }^{1}$, Astrid Eggert Boehs², Daiana de Mattia ${ }^{3}$, Carlos Gabriel Eggert Boehs", Maria \\ Francisca dos Santos Daussy ${ }^{5}$
}

${ }^{1}$ Ph.D. in Nursing. Professor of the Departamento de Enfermagem and of the Graduate Program in Nursing (GPN) of
Universidade Federal de Santa Catarina (UFSC). Santa Catarina, Brazil. E-mail: selma@ccs.ufsc.br
${ }^{2}$ Ph.D. in Nursing. Professor of the Departamento de Enfermagem and of the GPN/UFSC. Santa Catarina, Brazil. E-mail:
astridboehs@hotmail.com
${ }^{3}$ Family Health Specialist. Care Nurse of the Serviço de Hemoterapia of the HU/UFSC. Santa Catarina, Brazil. E-mail: daimattia@
gmail.com
${ }^{4}$ Ph.D. student of the Graduate Program in Business Administration of Universidade Positivo. Santa Catarina, Brazil. E-mail:
cgboehs@gmail.com
${ }^{5}$ Master's student of the Graduate Program in Public Health of UFSC. Head of the Departamento de Ensino e Serviço em Saúde
of the Municipal Health Secretariat of Florianópolis. Santa Catarina, Brazil. E-mail: frandaussy@yahoo.com.br

ABSTRACT: This qualitative study used a case study approach with the aim of analyzing the cooperation between the Nursing Course of the Federal University of Santa Catarina and the Municipal Health Secretariat of Florianópolis, from the Pró-Saúde I Project. The data, from documentary sources and interviews, were analyzed using the directed content analysis technique, and interpreted considering the Cooperative Interorganizational Relationships Model. The results show commitment to formalize the project between both institutions, at a strategic level, followed by negotiations and commitments, culminating with a modified project and a new agreement regulating the partnership. For its implementation, the Management Committee was responsible for making effective, in a cyclic way, the relationship for the proposed activities. It is concluded that there was approximation between the institutions at different levels, reflected in the cooperation within the healthcare units for education-service integration, with the aim of redirecting the nursing training.

DESCRIPTORS: Nursing. Education-Care Integration. Brazilian National Health System.

\section{COOPERAÇÃO E RELACIONAMENTO ENTRE INSTITUIÇÕES DE ENSINO E SERVIÇO DE SAÚDE: O PRÓ-SAÚDE ENFERMAGEM}

\begin{abstract}
RESUMO: Pesquisa qualitativa, com abordagem de estudo de caso, e o objetivo de analisar a cooperação entre o Curso de Enfermagem da Universidade Federal de Santa Catarina e a Secretaria de Saúde Municipal de Florianópolis, a partir do Projeto Pró-Saúde I. Os dados, de fontes documentais e entrevistas, foram analisados pela técnica de análise de conteúdo dirigida, interpretados à luz do modelo de relações interorganizacionais cooperativas. Os resultados mostram comprometimento para formalizar o projeto entre as duas instituições, em nível estratégico, seguido de negociações e compromissos, culminando com projeto modificado e um novo convênio regulando a parceria. Para sua execução, o Comitê Gestor foi responsável pela efetivação, de forma cíclica, das relações para as atividades propostas. Conclui-se que houve aproximação das duas instituições nos diferentes níveis, refletindo na cooperação dentro das unidades de saúde para a integração ensino-serviço, com vista à reorientação da formação em enfermagem.
\end{abstract}

DESCRITORES: Enfermagem. Integração Docente-Assistencial. Sistema Único de Saúde.

\section{COOPERACIÓN Y RELACIONAMIENTO ENTRE INSTITUCIONES DE ENSEÑANZA Y SERVICIO DE SALUD: EL PRO SALUD ENFERMERÍA}

RESUMEN: Investigación cualitativa, con abordaje de estudio de caso, con el objetivo de analizar la cooperación entre el Curso de Enfermería de la Universidad Federal de Santa Catarina y la Secretaría de Salud Municipal de Florianópolis, a partir del Proyecto Pro Salud I. Los datos, de fuentes documentales y entrevistas, fueron analizados por la técnica de análisis de contenido dirigida, interpretados a la luz del Modelo de Relaciones Interorganizacionales Cooperativas. Los resultados muestran compromiso para formalizar el proyecto entre ambas instituciones, a nivel estratégico, seguido de negociaciones, culminando con el proyecto modificado y un nuevo convenio regulador. Para su ejecución, el Comité Gestor fue responsable por efectuar, de forma cíclica, las relaciones para las actividades propuestas. Se concluye que hubo una aproximación de las instituciones en diferentes niveles, reflejando la cooperación en las unidades de salud para la integración enseñanza-servicio, para la reorientación de la formación en Enfermería.

DESCRIPTORES: Enfermería. Servicios de Integración Docente Asistencial. Sistema Único de Salud. 


\section{INTRODUCTION}

The National Program of Reorientation of Professional Formation in Health (Pró-Saúde), ${ }_{1}^{1}$ originated from the governmental cooperation initiative between the health and education sectors, in order to implement the National Curriculum Guidelines (NCGs) in the undergraduate courses of the health area. It is an educational reform in a multidisciplinary context, ${ }^{2}$ initially including the courses of medicine, nursing and dentistry (Pró-Saúde I) in 2005, and later, in 2007, expanded to the 14 health area professions (Pró-Saúde II). ${ }^{3}$ Both movements followed the recommendations of the National Health Council, being, with the first movement, to guide the formation of these professionals toward primary healthcare, since the professions composed the staff of the Family Health Strategy. With the second movement, to strengthen the inclusion of other professionals through the Family Health Strategy Support Centers. ${ }^{2-3}$

The main focus of Pró-Saúde I is on education-service integration, aiming to ensure an integral approach to the health-disease process with emphasis on primary healthcare and to promote changes in the provision of healthcare services to the population. ${ }^{1}$ After the intense movement toward redirecting health education in the country, evaluations and reflections ${ }^{4-9}$ regarding the education-service integration have highlighted advances and challenges.

In the context of organizational studies, it is considered that interorganizational relationships can be structured varying according to the degree of formalization and standardization, the importance given by the parties to the relationship, and the frequency and degree of symmetry of the transactions, among other aspects. ${ }^{10}$ There are several analysis models for these relationships, including the Cooperative Interorganizational Relationships $(\mathrm{CIRs})^{11}$ model, which situates interorganizational relationships through cyclical processes, covering the construction of the relationship, its maintenance, and the expansion of the transactions between the parties, up to its eventual closure. In this model, the dynamicity and temporality are analyzed, conceiving the notion that, in the interorganizational interaction process, phases arise with different characteristics: negotiation - the existence of formal and informal processes of interaction and the search for information between the parties; commitment - when the terms and structures of governance are established through formal and informal processes, which include the expectations of the parties regarding what each partner will give and receive in the relationships, agreements and contracts; and implementation - the step in which the commitments and rules are carried out. ${ }^{11}$ This model was used to analyze the relationships between Brazilian companies in the technology sector, ${ }^{12}$ in relationships between universities and biotechnology companies, ${ }^{13}$ and also in researching the communication between universities and companies in the relationship phases. ${ }^{14}$

In mid-2006, the Nursing Undergraduate Course of Santa Catarina Federal University (UFSC), as well as the courses in medicine and dentistry were awarded the Pró-Saúde I Project, in partnership with the Municipal Health Secretariat of Florianópolis (MHSF). The choice of MHSF occurred because there was already a formal agreement and a Teaching-Care Integration program with the health courses.

This study aimed to analyze the cooperation established in the partnership between the Nursing Course of UFSC and the MHSF, defined by the Pró-Saúde I project, through the prism of the CIRs model, ${ }^{11}$ both at the strategic level, involving the leaders of the two institutions, as well as at the tactical level of the project's management, coordinated by teachers of UFSC and nurses of the MHSF.

\section{METHOD}

This qualitative case study was carried out through the selection of a case of cooperation between the Undergraduate Nursing Course of UFSC and the MHSF studied in depth.

Data collection took place on two levels. The first was through semi-structured interviews with strategic level leaders of the two institutions and from formal documents that record the cooperation (two projects and four reports). Eight recorded and transcribed interviews were carried out with members of the strategic level, four from UFSC and four from the MHSF. The inclusion criteria were: respondents who were responsible for designing the project in 2005 and the current managers involved with the education-service integration. Data collection was performed by the authors using a semi-structured interview script and a survey form for the documentary data, from November 2011 to March 2012.

The second level consisted of the consultation of documents prepared by the Management Committee responsible for implementing the Nursing Pró-Saúde Project. The set of documents included the project designs of the $1^{\text {st }}$ and $2^{\text {nd }}$ steps 
of the Pró-Saúde, the corresponding reports, with their respective appendices and attachments, the minutes of the monthly meetings and the minutes of the extended biannual meetings with the nurses of the healthcare units, the statutes, and the normative instructions of the Ministry of Health and the Pan American Health Organizations(PAHO). It should be clarified that the Pró-Saúde Project was formulated for implementation in three stages (not to be confused with the phases of relationship discussed by the Cooperative Interorganizational Relationships Model). Each step corresponded to a specific timeline and budget, for completion within a 12 month period. In the case of the Nursing Pró-Saúde Project, the first step was conducted from 2007 to 2008, and the second, from 2009 to 2010. The third and final step began in 2012.

The data analysis followed the directed content analysis technique, with the relationship phases constituting pre-categories. ${ }^{15}$ The data were interpreted from the relationship phase perspective proposed by the CIRs model. ${ }^{11}$

The study fulfilled the recommendations of Resolution 196/96 of the National Health Council, with the guarantee of anonymity and the free prior informed consent of the respondents. It was approved by the Ethics Committee of UFSC, under protocol n. 2186/11.

\section{RESULTS AND DISCUSSION}

The results concerning the relationship and the cooperation between the institutions studied were analyzed and interpreted based on the CIRs model. ${ }^{11}$ In this model, the phases of negotiation, commitment and implementation occur in a repetitive sequence according to the situations faced by the interpretation of the parties regarding the interaction process.

The description and analysis of the relationship phases, at the strategic level and management committee level, here also called the tactical level, cover the period from 2005 to 2010 . The aim was to identify, throughout this period, the facts described in the interviews and documents that could be associated with the characterization of the relationship phases: negotiation $(\mathrm{N})$, commitment (C) and implementation (I), which will be represented by the letters $\mathrm{N} 1$ to $\mathrm{N} 6, \mathrm{C} 1$ to $\mathrm{C} 6$, and I1 to I2, as shown in table 1 .

Table 1 - Organizational relationship phases at the strategic and management committee levels of the Nursing Pró-Saúde I Project, according to the time line (2005-2010)

\begin{tabular}{|c|c|c|c|c|c|c|}
\hline Level & $\mathbf{2 0 0 5 / 2 0 0 6}$ & $\mathbf{2 0 0 6}$ & $\mathbf{2 0 0 7}$ & $\mathbf{2 0 0 8}$ & $\mathbf{2 0 0 9}$ & $\mathbf{2 0 1 0}$ \\
\hline Strategic & $\mathrm{C} 1$ & $\mathrm{~N} 1 \mathrm{C} 2$ & $\mathrm{~N} 2 \mathrm{C} 3$ & & & \\
\hline $\begin{array}{c}\text { Tactical (Manage- } \\
\text { ment Committee) }\end{array}$ & - & - & $\mathrm{I} 1 \mathrm{~N}, \mathrm{C}, \mathrm{I})$ & $\begin{array}{c}\mathrm{I} 1(\mathrm{~N}, \mathrm{C}, \mathrm{I}) \\
\mathrm{N} 2 \mathrm{C} 3\end{array}$ & $\mathrm{I} 2(\mathrm{~N}, \mathrm{C}, \mathrm{I})$ & $\mathrm{I} 2(\mathrm{~N}, \mathrm{C}, \mathrm{I})$ \\
\hline
\end{tabular}

\section{Commitment (C1)}

In December 2005, when the announcement of the Pró-Saúde I Project was made, the respondents of UFSC indicated the difficulty of interacting with the agents of the MHSF, arising from the political change in its management. Thus the coordinators of the courses informally sought the information necessary for the drafting of the project. This fact was also corroborated by the respondents of the MHSF, who said that in this phase they only received reports and did not participate in the process. The formal commitment between the coordination of the health courses at UFSC and the MHSF occurred with the signing of the Nursing Pró-Saúde I Project by the managers of the two institutions, at the beginning of 2006. This is corroborated in the analysis of the motivations and objectives for the achievement of the project, in which the focus was to seek cooperation with the MHSF, aiming to cre- ate conditions for the implementation of the new curriculum of 2001, regulated by the NCG, without mentioning any objective related to the healthcare service and its users in the context of the MHSF.

Thus, in this first interorganizational relationship moment, there was no negotiation phase to express the expectations and motivations of joint actions, but only the commitment phase (C1) to formalize the project between the two institutions. It is considered that the commitment of signing the project was possible because there was already a long history, mentioned by the respondents, of formal and informal relationships between UFSC and the MHSF.

\section{Negotiation and commitment}

The N1C2 phase, negotiation 1 and commitment 2, commenced with the approval by the Ministry of Health and PAHO, in the first half of 
2006. Requirements by the funding agencies for financial adjustments that should be made jointly, led the UFSC team to search for a negotiation and to be faced with a new scenario, the recently confirmed Health Secretary and team of managers and technicians of the MHSF. This negotiation phase lasted 6 months, with several meetings at the strategic level of the two institutions. In these meetings, many questions from the MHSF were raised regarding the presence and the distribution criteria for the students in the healthcare units, among others, characterizing a moment of active interaction and search for information about the project and about the presence of the students in the healthcare units by the counterparty, in this case the MHSF. The negotiation phase (N1) culminated with a new commitment (C2), which led to the reformulation of the Pró-Saúde I Project, to the organization of the flow of students and professors in the healthcare units, and to the need to revise the agreement between the two institutions .

In the following year (2007), new relationship steps were identified listed as the N2C3, Negotiation 2 and Commitment 3, with the open participation of all courses involved in the PróSaúde I Project at UFSC and of the strategic level of the MHSF, which culminated in the transformation of the old Teaching-Care Program into the Teacher Care Network (TCN) ${ }^{16}$ with the drafting and signing of the agreement between the parties. The statement of one respondent from the MHSF reflects this moment: [...] from there many meetings were held at management level, interspersed with expanded seminars with all the courses of the health area [...]. This was a big jump, because in these seminars discussions about how to integrate the students into the service took place and the statute which formalized everything was simultaneously constructed. The positive in all this was that on both sides there were people wanting to unite the interests of the two sides (E3).

It should be noted that, in the years 2006 and 2007 , at the strategic level of interaction, formal processes took place, such as meetings and seminars, as well as informal processes from the conversation opportunities and mutual understanding between the parties. In addition, the respondents from the university, when reporting the achievement of the objectives of the Pró-Saúde I Project claimed that the availability of the financial resources was important because it led the managers to the negotiating table, giving the university a certain bargaining power when discussing goals and objectives of cooperation with the counterparty conditioned to this availability. These data reveal the importance of the temporal and procedural analysis of the interorganizational relationship and of the content of the interaction processes, ${ }^{11}$ demonstrating the basis for the balance between formal and informal elements for success in the cooperation.

\section{Implementation}

This comprehends the solidification of commitments through the interaction of organizational roles and interpersonal interactions. In this phase, the commitments and rules are carried out, with the initial formal designation of roles and behaviors to be performed reducing the uncertainty in the relationship between the organizations and the interactions between the parties become predictable. ${ }^{11}$

According to the documentary evidence, in March 2007, with the financial credit granted by the Ministry of Health/PAHO, the implementation (I1) of the Nursing Pró-Saúde Project was effectively initiated, coordinated by two professors of UFSC. In the middle of that year, the first joint meeting was held with a nurse of the MHSF, with internal negotiations regarding the allocation of the financial resources and the joint responsibilities for the proposed activities. In the second half of the year, the biannual meeting with the nurses of the healthcare units was held. The meetings of the future Management Committee, with two teachers and a nurse of the MHSF, began to be formally held monthly, from the end of 2007, with them recorded in the minutes and with the establishment of goals.

Only in 2008 was this Committee formalized and expanded with the participation of four more teachers, taking responsibility for the activities henceforth called subprojects. On behalf of the MHSF only one nurse coordinator of the Department of Teaching and Service participated monthly and, sporadically, other nurses started to collaborate and coordinate subprojects, such as the implementation of the Nursing Care Systematization (NCS). In July 2008 the name of Management Committee appeared in the minutes for the first time, with the concern for the integration of students and representation from the community. The Committee started to take the role of communicating with the strategic level, participating in the monthly meetings of the TCN and with the operational level of the Pró-Saúde Project, i.e., that of the healthcare units, where the education-care activities were performed, through the extended biannual meetings with nurses and professors. The formal structure of the Management Committee 
with its regular operation made possible the joint implementation of the proposed activities on two axes of the Nursing Pró-Saúde Project1: theoretical guidance and scenarios of the practice.

At the end of 2008, the Management Committee negotiated and assumed a new commitment to a second step covering the period 2009-2010. It is important to highlight that, for this period, objectives for the education-service integration were achieved, unlike the situation in the $1^{\text {st }}$ stage, in which the main concern was centered on the curriculum. In the project, it was specified that the development of the actions would be between the Undergraduate Nursing Course and the health services, in order to contribute to the qualification of the education practices, of the healthcare, of the management, and of the social participation, as well as to the generation of knowledge, aiming to strengthen the Brazilian National Health System (SUS).

The implementation (I2) of this second step occurred from a series of interactions, coherent to the CIRs model, ${ }^{11}$ in which the people involved became more known to one another and could increasingly employ informal processes, through means of interpersonal relationships, rather than relationships based only on formal processes.

In a cyclic way and internal to the components of the committee, there were negotiations, commitments and the implementation of activities in order to meet the objectives established in the agreements made at the strategic level. Table 2 presents a summary of the main objectives and activities performed.

Table 2 - Main highlights of the implementation of the Nursing Pró-Saúde Project/UFSC. Period 2007-2010

\begin{tabular}{|c|c|}
\hline Period & Activities \\
\hline 2007 & Internal organization of the working group for the financial implementation of the project. \\
\hline \multirow{3}{*}{ 2007-2008 } & External consultants for the implementation of the project. \\
\hline & Creation of Nursing protocols and manuals. \\
\hline & Subprojects: NCS* + reference and counter reference. \\
\hline \multirow{4}{*}{$2007-2010$} & $\begin{array}{l}\text { Teaching-Service Integration Seminars: (Meeting of the nurses) conducted biannually }(2007 / 2,2008 / 1 \text {, } \\
2008 / 2,2009 / 1,2009 / 2 \text { and 2010/2). }\end{array}$ \\
\hline & Costs of materials and equipment. \\
\hline & $\begin{array}{l}\text { Definition of fields for all the semesters of the nursing course (except semesters } 3 \text { and } 4 \text { ) and allocation } \\
\text { of students in the practice fields. }\end{array}$ \\
\hline & Self-organization establishing schedule of biannual meetings. \\
\hline 2008 & Development of the Nursing Pró-Saúde Project step 2. \\
\hline \multirow{4}{*}{ 2008-2010 } & $\begin{array}{l}\mathrm{CCW}{ }^{* *} \text { - insertion of nurses into the evaluation of the CCW, of the internship of the } 8^{\text {th }} \text { semester, and } \\
\text { participation in research groups of the GPN/UFSC }{ }^{* * *} \text {. }\end{array}$ \\
\hline & $\begin{array}{l}\text { Instruction/training/courses/TREW }{ }^{\dagger}(2008,2009,2010) \text { : emphasis on training in immunization }=15 \\
\text { events of } 40 \mathrm{~h} \text {. }\end{array}$ \\
\hline & Promotion of two local events of the reference/counter-reference subproject. \\
\hline & Technical production: budget and printing of manuals, protocols, teaching materials and student guide. \\
\hline 2009 & Definition of criteria for participation in events. \\
\hline \multirow{4}{*}{2010} & Registration of professors in the information system - electronic medical records of the MHSF+†. \\
\hline & Development of the Nursing Pró-Saúde Project step 3. \\
\hline & Management Committee - included in the Academic System and as an extension project: PCNC ${ }^{\dagger+\dagger}$ \\
\hline & Development of the internal regulations of the PCNC. \\
\hline
\end{tabular}

"NCS: Nursing Care Systematization; ${ }^{* *}$ CCW: Course Conclusion Work; ${ }^{* * *}$ GPN/UFSC - Graduate Program in Nursing; †TREW: Teaching Research and Extension Week; ${ }^{+\dagger}$ MHSF: Municipal Health Secretariat of Florianópolis; ${ }^{+t+P C N C}$ : Primary Care Nursing Committee.

At the end of the implementation of step 2, the Management Committee was transformed into the Primary Care Nursing Committee (PCNC), and institutionalized in 2010. It was maintained as a channel for dialogue between the Undergraduate Course and the nursing staff of the MHSF and also with the other courses through the TCN.
The factors that led to the achievement of the implementation objectives of the project, highlighted by the respondents from both institutions were: the long history of relationships between the Nursing Course of UFSC and the MHSF, and the organized and constant actions of the Management Committee with the presence of the representatives of both institutions. 
Despite the positive interaction, some conflicts took place and led to negotiations, such as, the establishment of criteria for the allocation of financial resources for participation in scientific events, an action initiated in late 2009 and approved by the Management Committee in 2010. The choice of sites for supervised internships and practical classes was also a potential source of conflict between the two institutions and, with repeated negotiations and agreements, was finalized both in the Management Committee level meetings as well as in the expanded meetings between nurses and teachers.

Regarding the still existing problems and the expectations with respect to the members of the institutions, the respondents of both institutions primarily spoke about what happened daily in the healthcare units. The arguments of the respondents of the MHSF revolved around the institutional differences, stressing that the aim of the education institution is the formation, whereas, in the health service: there are clients waiting at the door to be attended (E8), showing the existence of different dynamics. The respondents of the MHSF repeatedly mentioned the turnover of students and teachers and their practice within a time limited to each semester, there is a lack of continuity for the work of the students (E1). To minimize such conflicts, the necessity was highlighted for dialogue and better understanding of the decisions and processes of the education institutions by the MHSF, both at the strategic level and in the healthcare units.

It is important to note that, according to the documentary data, in the implementation of the Nursing Pró-Saúde Project, the actions related to pedagogical guidance were performed only by the teachers of UFSC, who evaluated the curriculum without the participation of the care nurses. Therefore, in this context, the opportunity was lost for the perspective of the nursing staff of the MHSF in relation to their teaching role, as well as for discussing the dynamics and logic of the work of the two institutions. Conversely, the more optimistic respondents from the university argued that there had been advances and that the differences in expectations were diminishing, as joint planning had already occurred.

These differences are also highlighted in the literature concerning the barriers that still exist for the formation of healthcare professionals in the pursuit of integral care in the SUS. ${ }^{5}$ Among the difficulties is the integration of academia and work, ${ }^{5,7}$ where the expectation regarding the role of each part is emphasized, in which the university understands that it must create and transmit knowledge, leading it to define the objectives and the organizational form of the practical classes and internships. Conversely, the health services complain that the teachers and students do not take the workers of the health service into account, ${ }^{7}$ with distancing and ceremonious treatment between the parties, where each performs a different action in the healthcare units. ${ }^{8}$ This distancing creates difficulties in the formation opportunities. Specifically with regard to the formation of nurses, ${ }^{4}$ there are important gaps to be filled related to activities developed in practical classes and internships in primary care. These gaps refer to the curricular evaluation, aiming to valorize the exercise of the professional practice, from the actions specific to the nurse, and to strengthen the performance of the students in the multidisciplinary context, having the SUS as the reference.

Despite the difficulties, the maintenance of the Management Committee, remodeled as the Primary Care Nursing Committee, allowed the balance between formal and informal processes in the relationship, in which the problems within the constant movements of negotiation, commitment and implementation of activities are bought into focus.

\section{FINAL CONSIDERATIONS}

From the comprehension of the cyclical phases of negotiation, commitment and implementation of the Pró-Saúde I Project, between the Nursing Course of UFSC and the MHSF, it can de considered that the objective of education-service integration, with a view to redirecting the formation for the consolidation of the SUS, received a strong boost with the signing of the agreement between the institutional managers. Its development was positive and favorable in the subsequent periods, even with conflicts, which often resolved themselves into new phases of negotiation and compromise by the coordinators and participants of the Management Committee.

The interaction process analyzed, from the perspective shared by the members of both institutions, revealed conflicts of interest and differences in expectations. However, such situations were developed and overcome by the members at the Management Committee level, in the different instances of practice.

It was concluded that the cooperation for the establishment of the Nursing Pró-Saúde Project 
induced, and continues to induce an increase in the relationships between the nursing course and the MHSF, with these relationships being anchored in socially constructed mechanisms, which are continually shaped and restructured by the actions and interpretations of the parties involved.

Further studies could be undertaken with a focus on the interorganizational relationship between the university and the healthcare units in the context of the learning process, as well as the reflections of the process of cooperation regarding the community served. Interinstitutional relations never present a single observational perspective. To comprehend the view of the organizations and actors involved in the interinstitutional relationships it is essential to deal with conflicts and cooperation processes.

\section{REFERENCES}

1. Ministério da Saúde (BR), Ministério da Educação. Programa Nacional de Reorientação da Formação Profissional em Saúde - Pró Saúde. Brasília (DF): MS, 2007.

2. Ferreira JR, Cury GC, Campos FE, Haddad AE, Gusso GDF. A construção de parcerias como estratégia para o sucesso do Pró-Saúde. Cad ABEM. 2007 Out; 3:53-61.

3. Haddad AE, Brenelli SL, Cury GC, Puccini RF, Martins MA, Ferreira JR, et al. Pró-Saúde e PETSaúde: a construção da política brasileira de reorientação da formação profissional em saúde. Rev Bras Educ Med [online]. 2012 [acesso 2012 Out 13]; 36(supl.1) Disponível em: http://www. scielo.br/scielo.php?script $=$ sci_arttext\&pid $=$ S0100$55022012000200001 \& \operatorname{lng}=$ pt\&nrm=iso\&tlng=pt

4. Medeiros VC, Peres AM. Atividades de formação do enfermeiro no âmbito da atenção básica à saúde. Texto Contexto Enferm. 2011; 20(Esp):27-35.

5. Costa RSC, Miranda FAN. Formação profissional no SUS:oportunidades de mudanças na perspectiva da Estratégia da Saúde da Família. Trab Educ Saude. 2008 Nov-Dez; 6(3):503-17.

6. Silva MAM, Amaral JHL, Senna MIB, Ferreira EF. O Pró-Saúde e o incentivo à inclusão de espaços diferenciados de aprendizagem nos cursos de odontologia no Brasil. Interface (Botucatu) [online]. 2012 [acesso 2012 Out 13]; 16(42):707-17. Disponível em: http:/ / www.scielo.br/scielo.php?script=sci_ arttext\&pid=S1414-32832012000300010\&lng=pt\&n $\mathrm{rm}=\mathrm{iso \& t} \operatorname{lng}=\mathrm{pt}$

7. Albuquerque VS, Gomes AP, Rezende CHA, Sampaio MX, Dias OV, Lugarinho RM. A integração ensino-serviço no contexto dos processos de mudança na formação superior dos profissionais de saúde. Rev Bras Educ Medic. 2008 Set; 32(3):356-62.

8. Henriques RLM. Interlocução entre ensino e serviço: possibilidades de resignificação do trabalho em equipe na perspectiva da construção social da demanda. In: Pinheiro R, Mattos RA, organizadores. Construção social da demanda: direito a saúde, trabalho em equipe, participação e espaço público. Rio de Janeiro (RJ): CEPES, UERJ, ABRASCO; 2010. p.149-61.

9. Finkler M, Caetano JC, Ramos FRS. Integração "ensino-serviço" no processo de mudança na formação profissional em odontologia. Interface Comun Saúde Educ. 2011 Out-Dez; 15(39):1053-70.

10. Hall RH. Organizações: estruturas, processos e resultados. $8^{\mathrm{a}}$ ed. São Paulo (SP): Pearson/Prentice Hall; 2004. p. 191-222.

11. Ring PS, Van de Ven AH. Developmental processes of cooperative interorganizational relationships. Academy of Management Review. 1994 Jan; 19(1):90-118.

12. Boehs CGE, Segatto-Mendes AP. Identificação de mecanismos de controle em alianças estratégicas para o desenvolvimento tecnológico:um estudo múltiplos casos no setor metal-mecânico ao longo das fases de relacionamento. Rev Adm Contemp. 2007 Jul-Set; 11(3):199-221.

13. Cunha CR, Melo MCOL. A confiança nos relacionamentos interorganizacionais:o campo da biotecnologia em análise. RAE Electron [online]. 2006 [acesso 2012 Ago 6]; 5(2). Disponível em: http:/ / www.scielo.br/scielo.php?script=sci_ arttext\&pid=S1676-56482006000200009\&lng=en\&n $\mathrm{rm}=\mathrm{iso} \& \mathrm{tlng}=\mathrm{pt}$

14. Cruz EMK, Segatto AP. Processos de comunicação em cooperações tecnológicas universidade-empresa: estudos de caso em universidades federais do Paraná. Rev Adm Contemp. 2009 [acesso 2012 Set 21]; 13(3):430-49. Disponível em http:/ / www.scielo. br/pdf/rac/v13n3/v13n3a06.pdf

15. Hsieh HF, Shannon SE. Three approaches to qualitative content analysis. Qual Health Res. 2005 Nov; 15(9):1277-88.

16. Reibnitz KS, Daussy MFS, Silva CAJ, Reibnitz MT; Kloh D. Rede docente assistencial UFSC/SMS de Florianópolis: reflexos da implantação dos projetos Pró-Saúde I e II. Rev Bras Educ Med. 2012 Mar; 36(1 suppl 2):68-75. 